\title{
A new method for determination of mandelic acid excretion at low level styrene exposure
}

\author{
A. SLOB \\ Netherlands Institute for Preventive Medicine TNO, Wassenaarseweg 56, Leiden, \\ The Netherlands
}

\begin{abstract}
Slob, A. (1973). British Journal of Industrial Medicine, 30, 390-393. A new method for determination of mandelic acid excretion at low level styrene exposure. A method is described for the determination of mandelic acid in urine. It is possible to determine styrene exposure levels in the air down to $5 \mathrm{mg} / \mathrm{m}^{3}$. The method is based on ethyl acetate extraction of the urine, followed by a paper chromatographic combined with a gas chromatographic separation.

The method was evaluated in industrial situations and compared with a method used frequently hitherto. The inclusion of a hydrolytic step indicates that part of the mandelic acid is excreted in conjugated form. Workers exposed to styrene levels in the air of less than 5 $\mathrm{mg} / \mathrm{m}^{3}$ showed a very significant increase in mandelic acid excretion compared with "no exposure' conditions.
\end{abstract}

During recent years a considerable increase in the use of styrene has occurred. It is widely used for the production of synthetic resins and in the rubber and plastic industries (Browning, 1965). In the United States alone, consumption is estimated to be 1000000 tons per year (Bardodej and Bardodejova, 1970).

Because of the extensive use of styrene in industry, and its considerable toxicity, there is a real need for an exposure test for this substance that can be relied on, even at low styrene exposure levels.

The methods used previously were based on a colorimetric reaction or on ultraviolet-absorption. These methods are, therefore, not very specific. For non-exposed persons, mandelic acid excretions of 50-150 mg/l (Ohtsuji and Ikeda, 1970) were found.

Even one of the most discriminating methods, which we adopted for comparison, showed considerable nonspecific absorption. This method (Bardodej, Fiserová-Bergerová, and Ledrer, 1964) is based on the conversion of mandelic acid into benzaldehyde by means of cerium (IV) sulphate oxidation. The benzaldehyde is distilled off with water vapour and determined spectrophotometrically at a wavelength of $245 \mathrm{~nm}$.
Figure 1 shows the absorption spectra for a benzaldehyde solution, a urine extract of a nonexposed person, and the same urine with $10 \mathrm{mg} / 1$ of

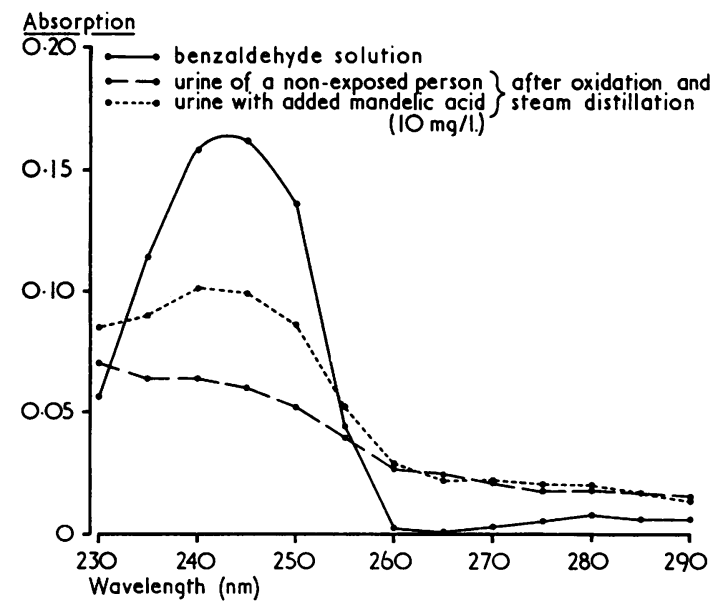

Fig. 1. Absorption spectra in the UV area with the oxidation method. 
mandelic acid added and then oxidized. The absorption spectrum for the urine extract of the nonexposed person does not resemble very closely the benzaldehyde spectrum. A nonspecific absorption, equivalent to $20 \mathrm{mg} / 1$ mandelic acid, is observed. When mandelic acid is added to the urine, which is then oxidized, an easily recognizable shift to the spectrum of benzaldehyde is seen. However, excretions of mandelic acid of less than $20-30 \mathrm{mg} / \mathrm{l}$ cannot be determined in this way.

We therefore developed a new method for the determination of mandelic acid excretion in the urine. It is about 10 times more sensitive than existing methods.

\section{Experimental procedure}

Urine samples were collected for a period of 8 hours both during the working day and at the weekend.

Acidify an aliquot $(10 \mathrm{ml})$ of urine with $10 \mathrm{~N}$ hydrochloric acid $(0.5 \mathrm{ml})$; extract the mandelic acid successively with two $10 \mathrm{ml}$ portions of ethyl acetate. Combine the ethyl acetate extracts and remove the solvent by evaporation under reduced pressure using a Rotavapor (Büchi). Dissolve the residue in ethanol $(0.4 \mathrm{ml})$. Transfer $0.1 \mathrm{ml}$ of this ethanolic solution to a sheet of Whatman no. 1 paper and chromatograph the components using butan-1-ol, saturated with ammonia, as the mobile phase (ascending chromatography) for 16 hours. The Rf-value of mandelic acid in this system is $\mathbf{0} \cdot \mathbf{3}$. Standards are also run; spray the chromatographs with $3 \%$ ferric chloride solution in water to locate the mandelic acid zone. Cut out the same zone of the urinary chromatograph, extract successively with two portions $(5 \mathrm{ml})$ of ethyl acetate which has been previously acidified with $0 \cdot 1 \mathrm{~N}$ hydrochloric acid $(5 \mathrm{ml})$. Combine the extracts and remove the solvent under reduced pressure. Dissolve the residue in chloroform $(0.8 \mathrm{ml})$ and add N,O-bis (trimethylsilyl) acetamide $(0.2 \mathrm{ml})$. Warm to $60^{\circ} \mathrm{C}$ and maintain at this temperature for 1 hour to complete the silylation process. Inject $3 \mu \mathrm{l}$ of the silylated solution into a gaschromatograph (F \& M 402) using the following conditions:

Column length, 1.8 meter;

Stationary phase, $5 \%$ SE-52 on Gas Chrom Q (100120 mesh);

Temperature, $175^{\circ} \mathrm{C}$.

In order to evaluate the reproducibility of the method 10 replicate determinations of the mandelic acid concentration in one urine sample were conducted. The mean concentration was $26.8 \mathrm{mg} / \mathrm{l}$, standard deviation 0.8 $\mathrm{mg} / \mathrm{l}$ (coefficient of variation $3 \%$ ). For an amount of $20 \mathrm{mg} / \mathrm{l}$ of mandelic acid which had been added to eight different urine samples the average recovery was $93 \%$.

In order to evaluate the new gas chromatographic method in industrial situations we determined mandelic acid excretion in three individuals in a large synthetic resin plant. The determinations were made before and during cleaning of the reaction vessels. For comparison, the oxidation method (Bardodej et al., 1964) was used. In addition, we applied our method with an extra hydrolytic step included in order also to measure the mandelic acid excreted in conjugated form.

\section{Results}

The results of the comparison are shown in Table 1. It can be seen that there is good consistency between the different methods. Furthermore, even at high styrene exposure levels ( $G$ exposed) considerable nonspecific absorption is seen with the oxidation method. Part of the mandelic acid is excreted in conjugated form.

TABLE 1

MANDELIC ACID EXCRETION (mg/l) BEFORE AND DURING STYRene EXPOSURE MEASURED WITH THREE DifFerent METHODS

\begin{tabular}{|c|c|c|c|c|c|}
\hline & & & $I$ & $I I$ & $I I I$ \\
\hline $\mathbf{R}$ & $\begin{array}{l}\text { Non-exposed } \\
\text { Exposed }\end{array}$ & $\begin{array}{l}\ldots \\
\ldots\end{array}$ & $\begin{array}{l}43 \\
16\end{array}$ & $\begin{array}{r}5 \\
12\end{array}$ & $\begin{array}{l}10 \\
16\end{array}$ \\
\hline $\mathbf{P}$ & $\begin{array}{l}\text { Non-exposed } \\
\text { Exposed }\end{array}$ & $\begin{array}{l}\ldots \\
\ldots\end{array}$ & $\begin{array}{l}62 \\
90\end{array}$ & $\begin{array}{r}4 \\
61\end{array}$ & $\begin{array}{r}20 \\
118\end{array}$ \\
\hline G & $\begin{array}{l}\text { Non-exposed } \\
\text { Exposed }\end{array}$ & $\begin{array}{l}\ldots \\
\ldots\end{array}$ & $\begin{array}{r}25 \\
1066\end{array}$ & $\begin{array}{r}2 \\
349\end{array}$ & $\begin{array}{r}21 \\
598\end{array}$ \\
\hline
\end{tabular}

I Oxidation to benzaldehyde and measuring UVabsorption at $245 \mathrm{~nm}$ of steam distillate.

II GLC method without hydrolylic step.

III GLC method with hydrolytic step included.

Figure 2 shows the gas chromatogram of a urine extract from a non-exposed person, before and after mandelic acid addition. With this method an excretion of $2-3 \mathrm{mg} / \mathrm{l}$ can be determined.

These concentrations are in a relevant range for toxicological consideration. For, according to Bardodej (1964), a concentration of $125 \mathrm{mg} / 1$ in the urine results from the first 4 hours of exposure to a styrene concentration of $100 \mathrm{mg} / \mathrm{m}^{3}$ (TLV-USA $420 \mathrm{mg} / \mathrm{m}^{3}$, TVL-USSR $50 \mathrm{mg} / \mathrm{m}^{3}$ ) (American Conference of Governmental Industrial Hygienists, 1971).

\section{Discussion}

Urinary excretion of a number of different styrene metabolites has been proposed to measure styrene exposure levels, e.g.:

benzoic acid (Spencer, Irish, Adams, and Rowe, 1942)

hippuric acid (Carpenter, Shaffer, Weil, and Smyth, 1944; El Masri, Smith, and Williams, 1958)

mandelic acid (Bardodej, 1964; Ruvinskaya, 1966)

phenylglyoxylic acid (Ohtsuji and Ikeda, 1970). According to El Masri et al. (1958), the major metabolite of styrene is hippuric acid, at least in rabbits. In experiments with rabbits they found that 


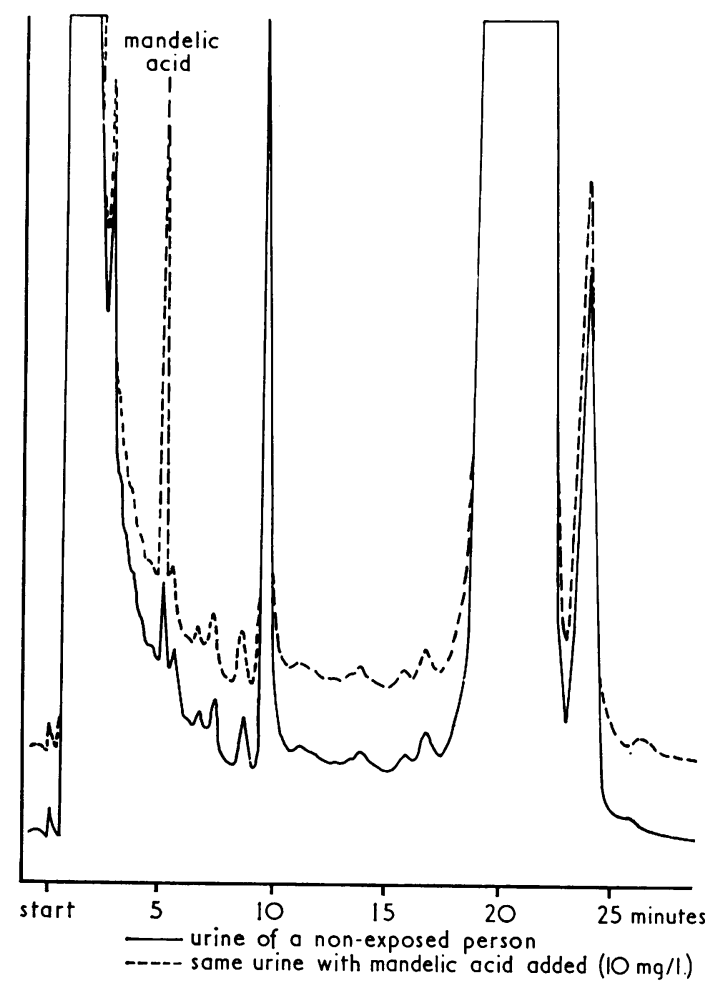

Fig. 2. Gas chromatograms of a urine extract, with and without added mandelic acid.

30 to $40 \%$ of the styrene was converted into hippuric acid.

However, with their inhalation experiments Stewart, Dodd, Baretta, and Schaffer (1968) could not detect an increase in hippuric acid excretion in man. A possible explanation may be the fact (Zielhuis, 1969) that the amount of hippuric acid endogenously excreted is already considerable, so that an increase due to styrene exposure can be detected only at very high exposure levels.

Bardodej (1964; Bardodej and Bardodejova, 1966) also conducted inhalation experiments and found that in man $60 \%$ of inspired styrene was retained in the respiratory tract. Of this amount, about $85 \%$ was metabolized to mandelic acid, while some phenylglyoxylic acid $(10 \%)$ was also formed. No increase in hippuric acid excretion could be detected. Later experiments at a different styrene exposure level were consistent with these results (Bardodej and Bardodejova, 1970).

In guinea-pigs, Ruvinskaya (1966) found that with inhalation experiments, as well as after subcutaneous injections, less styrene was converted into mandelic acid (20 to $30 \%$ of the administered dose).

The conclusion seems justified (Bardodej and Bardodejova, 1970) that the biotransformation of styrene in man differs considerably from that in animals.

However, Ohtsuji and Ikeda (1970) consider phenylglyoxylic acid excretion to be a better parameter for styrene exposure, especially at low level exposure. They based their conclusions on the excretion of both mandelic acid and phenylglyoxylic acid in industrial situations. These conclusions were reached in spite of the fact that phenylglyoxylic acid excretion is less than that of mandelic acid and that the ratio mandelic acid excretion to phenylglyoxylic acid excretion increases only at higher exposure levels. In our opinion, this is due to the fact that, for mandelic acid excretion at 'no exposure level', much higher values were detected $(50-150 \mathrm{mg} / \mathrm{l})$ than for phenylglyoxylic acid (10-30 mg/1).

With our meihod, even very low exposure levels of styrene can be distinguished, as can be seen from the data presented in Table 2. The excretions during exposure and at the weekend are shown for a group of workers exposed to very low levels of styrene. In most cases a difference was found for a styrene exposure level estimated as less than $5 \mathrm{mg} / \mathrm{m}^{3}$ and 'no exposure'.

TABLE 2

MANDELIC ACID ExCRETION OF EIGHT INDividuals BEFORE AND DURING THE WORKING DAY IN A Large Industrial Plant

\begin{tabular}{|c|c|c|c|c|c|c|}
\hline & & & & & \multicolumn{2}{|c|}{$\begin{array}{l}\text { Mandelic acid } \\
\text { excretion in: }\end{array}$} \\
\hline & & & & & $m g / l$ & $\mathrm{mg} / 8$ hours \\
\hline \multirow[t]{2}{*}{ R.I. } & I & $\ldots$ & .. & .. & $2 \cdot 0$ & 1.2 \\
\hline & II & .. & $\ldots$ & .. & $1 \cdot 8$ & 0.8 \\
\hline \multirow[t]{2}{*}{ H.A. } & I & .. & $\ldots$ & . & $2 \cdot 4$ & 1.0 \\
\hline & II & . & . . & .. & $2 \cdot 6$ & 0.5 \\
\hline \multirow[t]{2}{*}{ K.A. } & I & . & . & .. & $1 \cdot 2$ & $1 \cdot 0$ \\
\hline & II & . & . & . & 0.8 & 0.5 \\
\hline \multirow[t]{2}{*}{ B.U. } & I & .. & . & .. & $7 \cdot 2$ & $1 \cdot 4$ \\
\hline & II & .. & $\ldots$ & .. & 0.6 & $0 \cdot 3$ \\
\hline \multirow[t]{2}{*}{ S.T. } & I & . & .. & . & $3 \cdot 0$ & 0.9 \\
\hline & II & . & . & . & 1.4 & 0.6 \\
\hline \multirow[t]{2}{*}{ G.E. } & I & .. & . & .. & $2 \cdot 0$ & $1 \cdot 6$ \\
\hline & II & .. & $\ldots$ & . & 0.6 & 0.3 \\
\hline \multirow[t]{2}{*}{ H.O. } & I & .. & $\ldots$ & .. & 1.4 & 0.5 \\
\hline & II & .. & .. & .. & $2 \cdot 4$ & 0.5 \\
\hline \multirow[t]{2}{*}{ R.E. } & I & .. & . & .. & $26 \cdot 8$ & $10 \cdot 7$ \\
\hline & II & .. & .. & . & $7 \cdot 2$ & $0 \cdot 7$ \\
\hline
\end{tabular}

I during the working day.

II at the weekend. 
I wish to thank Miss A. Hoogeveen for skilful technical assistance. Dr. J. J. v.d. Kolk kindly provided the urine samples which were collected from the AKZO-plant in Arnhem.

\section{References}

American Conference of Governmental Industrial Hygienists (1971). Documentation of the Threshold Limit Values for Substances in Workroom Air, 3rd ed., pp. 235-236. Cincinnati, Ohio.

Bardodej, Z. (1964). Metalismus styréna. Českolovenská Hygiena, 9, 223-239.

- and Bardodejova, E. (1966). The metabolism of ethyl benzene, styrene, and $\alpha$-methylstyrene. Proceedings of the Fifteenth International Congress on Industrial Health, Vienna, II-1, 457-460.

- , and - (1970). Biotransformation of ethyl benzene, styrene, and $\alpha$-methylstyrene in man. American Industrial Hygiene Association Journal, 31, 206-209.

, Fiserová-Bergerová, V., and Ledrer, E. (1964). Polarographic determination of mandelic acid in the urine. (In Czech). Pracovni Lékařstvi, 16, 414-415.

Browning, E. (1965). Toxicity and Metabolism of Industrial Solvents, pp. 98-102. Elsevier, Amsterdam.
Carpenter, C. P., Shaffer, C. B., Weil, C. S., and Smyth, H. F. (1944). Studies on the inhalation of 1,3-butadiene; with a comparison of its narcotic effect with benzol, toluol, and styrene, and a note on the elimination of styrene by the human. Journal of Industrial Hygiene, 26, 69-78.

El Masri, A. M., Smith, J. N., and Williams, R. T. (1958). The metabolism of alkylbenzenes: phenylacetylene and phenylethylene (styrene). Biochemical Journal, 68, 199-204.

Ohtsuji, H., and Ikeda, M. (1970). A rapid colorimetric method for the determination of phenylglyoxylic and mandelic acids. British Journal of Industrial Medicine, 27, 150-154.

Ruvinskaya, S. E. (1966). Conversions of styrene in the body of experimental animals. Federation Proceedings, 25, (Translation supplement) T854-T856.

Spencer, H. C., Irish, D. D., Adams, E. M., and Rowe, V. K. (1942). The response of laboratory animals to monomeric styrene. Journal of Industrial Hygiene, 24, 295-301.

Stewart, R. D., Dodd, H. C., Baretta, E. D., and Schaffer, A. W. (1968). Human exposure to styrene vapor. Archives of Environmental Health, 16, 656-662.

Zielhuis, R. L. (1969). Experimentele blootstelling aan styreen. Tijdschrift voor Sociale Geneeskunde, 47, 92.

Received for publication 1 December 1972

Accepted for publication 28 February 1973 